\title{
Penerapan Model Pembelajaran Problem Based Learning Berbantuan Portofolio untuk Meningkatkan Pemahaman Konsep Matematika Peserta Didik Kelas XI Aph C SMK Negeri 1 Singaraja Tahun Pelajaran 2018/2019
}

\author{
${ }^{1}$ Ni Luh Kusuma Dewi, ${ }^{2}$ Ni Nyoman Parwati \\ 1,2Jurusan Pendidikan Matematika \\ Fakultas Matematika dan IImu Pengetahuan Alam, Universitas Pendidikan Ganesha, Singaraja Indonesia \\ Email: niluhkesumadewi12@gmail.com, nyoman.parwati@undiksha.ac.id
}

\begin{abstract}
Abstrak
Penelitian ini bertujuan untuk menganalisis peningkatan kemampuan pemahaman konsep matematika peserta didik terhadap penerapan model pembelajaran Problem Based Learning. Jenis penelitian ini adalah penelitian tindakan kelas yang dilaksanakan dalam dua siklus. Subjek penelitian ini adalah peserta didik kelas XI APH C SMK Negeri 1 Singaraja sebanyak 35 orang peserta didik pada semester ganjil Tahun Ajaran 2018/2019. Data hasil belajar peserta didik diambil melalui tes awal menggunakan soal uraian. Data yang telah terkumpul selanjutnya dianalisis secara deskriptif. Hasil penelitian menunjukkan bahwa rata-rata nilai hasil belajar mengalami peningkatan dari siklus ke siklus. Peningkatan tersebut dapat dilihat dari ketuntasan belajar siswa meningkat sebesar $6,17 \%$ dari $69,12 \%$ padda siklus I dan terakhir meningkat menjadi $75,29 \%$ pada siklus II. Pada siklus II, ketuntasan belajar peserta didik telah mencapai indikator keberhasilan yaitu $75 \%$. Peningkatan terjadi melalui model pembelajaran Problem Based Learning berbantuan portofolio dengan penekanan pada: (1) pembelajaran berpusat pada peserta didik, (2) pembelajaran berbasis pada masalah sehari-hari, (3) pemberian bimbingan dan motivasi kepada siswa.
\end{abstract}

Kata kunci: problem based learning, portofolio, matematika.

\section{Pendahuluan}

Pendidikan merupakan suatu proses untuk meningkatkan kecerdasan serta harkat dan martabat bangsa. Pendidikan dapat menjadikan seorang manusia menjadi manusia yang berkualitas dan mandiri sehingga mampu membangun dirinya dan masyarakat sekelilingnya serta dapat memenuhi kebutuhan pembangunan nasional dan bertanggung jawab atas pembangunan bangsa. Pendidikan adalah salah satu bentuk perwujudan kebudayaan manusia yang dinamis dan sarat perkembangan. Oleh sebab itu, perubahan atau perkembangan pendidikan adalah hal yang memang seharusnya terjadi sejalan dengan perubahan budaya kehidupan. Perubahan dalam arti perbaikan pendidikan pada semua tingkat perlu terus-menerus dilakukan sebagai antisipasi kepentingan masa depan. Perubahan pendidikan tersebut tidak terlepas dari perkembangan matematika. Matematika merupakan ilmu universal yang mempunyai peran penting dalam berbagai disiplin ilmu dan mendasari perkembangan teknologi modern. Matematika sebagai salah satu mata pelajaran yang sangat mendukung perkembangan ilmu pengetahuan dan teknologi memang perlu mendapat perhatian yang sangat serius.

Matematika berkenaan dengan ide-ide dan konsep-konsep yang abstrak. Konsepkonsep matematika tersusun secara hierarkis, terstruktur, logis dan sistematis mulai dari konsep yang paling sederhana, sampai konsep yang paling kompleks (Suherman, 2003:22). Konsep matematika yang dipelajari oleh peserta didik dapat saja kurang bermanfaat bahkan tidak bermanfaat sama sekali jika hal tersebut hanya dikomunikasikan oleh guru kepada peserta didik melalui satu arah. Tidak dapat disangkal bahwa konsep merupakan suatu hal yang sangat penting, namun bukan terletak pada konsep itu sendiri melainkan bagaiman konsep itu dipahami oleh peserta didik. Jadi dapat dikatakan bahwa pemahaman konsep merupakan salah satu bagian yang paling penting dalam pembelajaran matematika.

Pemahaman konsep adalah kesanggupan yang dimiliki seseorang untuk dapat menyatakan konsep dalam kata-kata sendiri, mengidentifikasi atau memberi contoh atau bukan contoh dari konsep, mengaplikasikan/menggunakan konsep dengan benar dalam 
berbagai situasi. Pemahaman konsep merupakan salah satu kecakapan atau kemahiran matematika yang diharapkan dapat tercapai dalam belajar matematika yaitu dengan menunjukkan pemahaman konsep matematika yang dipelajarinya, menjelaskan keterkaitan antar konsep dan mengaplikasikan konsep atau algoritma secara luwes, akurat, efisien, dan tepat dalam pemecahan masalah. Berdasarkan penjelasan di atas, maka pemahaman konsep perlu ditanamkan kepada peserta didik sejak dini yaitu sejak anak tersebut masih duduk di bangku sekolah dasar. Mereka dituntut mengerti tentang definisi, pengertian, cara pemecahan masalah maupun pengoperasian matematika secara benar. Hal tersebut akan menjadi bekal dalam mempelajari matematika pada jenjang pendidikan yang lebih tinggi. Pemahaman konsep matematika pun dipandang sebagai salah satu variabel penentu peningkatan prestasi belajar seorang peserta didik.

Pengamatan mengenai kemampuan pemahaman konsep matematika peserta didik peneliti laksanakan di kelas XI APH C SMK N 1 Singaraja. Berdasarkan hasil pengamatan yang dilakukan peneliti di SMK Negeri 1 Singaraja pada satu bulan pertama pelaksanakan kegiatan Program Pengalaman Lapangan (PPL) pada bulan Juli-Agustus 2018 di kelas XI AKL A yang terdiri dari 34 peserta didik, dan kelas XI APH C terdiri dari 34 peserta didik, peneliti sebagai guru Program Pengalaman Lapangan (PPL) berusaha melakukan pembelajaran berpusat pada peserta didik sebagai subjek pembelajaran bukan sebagai objek. Peneliti berusaha mengelola pembelajaran Matematika yang aktif diantaranya melalui kegiatan diskusi maupun tanyajawab, peneliti selalu melibatkan peserta didik dalam mengambil kesimpulan, namun pada kenyataannya hanya beberapa peserta didik yang ikut aktif dalam proses pembelajaran. Kendala lain yang ditemukan adalah peserta didik belum memiliki buku paket atau modul, cenderung mengharapkan materi dari guru, kemudian mencatat yang dapat membuat jam pelajaran yang seharusnya dapat digunakan sebagai latihan tidak dapat dimanfaatkan dengan baik. Akibatnya aktivitas pembelajaran kurang terarah. Melihat kondisi pembelajaran yang terjadi membuat guru sebagai pengelola pembelajaran kembali menyampaikan materi secara langsung.

Permasalahan-permasalahan tersebut pada akhirnya dapat berdampak pada hasil belajar peserta didik di kelas tersebut. Hal tersebut dapat dilihat dari nilai rata-rata ulangan harian materi statistika semester ganjil tahun ajaran 2018/2019 Tes awal ini terdiri dari 5soal dengan kriteria ketuntasan minimum (KKM) adalah 73. Berdasarkan tes awal yang dilaksanakan diperoleh bahwa rata-ratanilai peserta didik yaitu 68 dengan persentase ketuntasan sebesar $45 \%$. Nilai tertinggi dan nilai terendah yang diperoleh peserta didik berturut-turut, yaitu 80 dan 25 . Berdasarkan tes awal tersebut, peneliti melakukan analisis jawaban peserta didik yang dapat dilihat seperti tabel 1 berikut.

Tabel 1. Analisis tes awal kelas XI APH C SMK N 1 Singaraja

\begin{tabular}{|c|c|c|c|}
\hline Butir Soal & Jawaban Benar & Jawaban Salah & Tidak Menjawab \\
\hline Soal 1 & 32 orang & 2 orang & - \\
\hline Soal 2 & 28 orang & 4 orang & - \\
\hline Soal 3 & 16 orang & 17 orang & 1 orang \\
\hline Soal 4 & 15 orang & 19 orang & - \\
\hline Soal 5 & 5 orang & 25 orang & 4 orang \\
\hline
\end{tabular}

Berdasarkan tabel analisis diatas, diketahui bawasannya hanya sekitar $44,11 \%$ saja peserta didik yang mampu menjawab benaar pada butir soal nomor 4 dan hanya sekitar 17, $24 \%$ peserta didik yang mampu menjawab dengan benar soal nomor 5 . Butir soal nomor 4 dan nomor 5 merupakan butir soal aplikasi yang mengharuskan peserta didik untuk berpikir lebih. Dari butir soal 4 dan 5, kita dapat lihat mengenai kurangnya tingkat pemahaman konsep matematika peserta didik, terutama dalam mengaplikasikan konsep yang mereka dapatkan terhadap permasalahan yang diberikan.

Dari hasil tersebut disimpul kan bahwa kemandirian belajara yang dapat mendukung hasil belajar peserta didik kelas XI APH C di SMK Negeri1Singaraja perlu ditingkatkan. Berdasarkan identifikasi dan penyebab masalah tersebut dan materi yang akan dipelajari selanjutnya adalah materi persamaan dan fungsi kuadrat, diperlukan suatu tindak lanjut untuk 
mengatasi masalah yang ada sehingga mampu meningkat kan hasil dan aktivitas belajar matematika kelas XI APH C di SMK Negeri 1 Singaraja. Pemilihan tindakan juga harus disesuaikan dengan materi yang akan dipelajari. Salah satu model pembelajaran matematika yang berorientasi pada permasalahan terstruktur dan melibatkan peserta didik secara aktif melalui diskusi kelompok sekaligus menanamkan kepada peserta didik konsep yang diajarkan adalah model pembelajaran problem based learning (PBL).

Model pembelajaran problem based learning merupakan model pembelajaran yang menggunakan permasalahan dalam dunia nyata dan pembelajaran dipusatkan pada penyelesaian masalah. Pembelajaran didesain dalam bentuk pembelajaran yang diawali dengan struktur masalah yang berkaitan dengan konsep-konsep matematis yang akan diajarkan. Dalam model ini peserta didik membentuk kelompok diskusi sehingga peserta didik menjadi lebih aktif dan guru hanya berperan sebagai fasilitator. Semua informasi akan mereka kumpulkan melalui penelaahan materi ajar atau modul yang telah diberikan sebelumnya, ataupun melalui diskusi dengan teman sebayanya, untuk memecahkan masalah yang dihadapinya.

Model Pembelajaran PBL terdiri atas 5 tahapan yaitu pemberian masalah, mengorganisasikan peserta didik untuk belajar, membimbing penyelidikan individuan maupun kelompok, mengembangkan dan menyajikan hasil karya, serta menganalisis dan evaluasi. Pada tahap pemberian masalah peserta didik diberikan kesempatan untuk untuk mengidentifikasi masalah yang disajikan. Pada tahap mengorganisasikan peserta didik untuk belajar peserta didik mempunyai kesempatan untuk mengungkapkan ide dan mempelajari maslah yang telah mereka terima dengan teman-temannya. Selanjutnya, pada tahap membimbing penyelidikan individuan maupun kelompok peserta didik mempunyai kesempatan untuk berdiskusi dengan temannya disertai dengan bimbingan dari guru. Pada tahap mengembangkan dan menyajikan hasil karya peserta didik berdiskusi untuk menyajikan dan mengembangkan hasil diskusinya yang nantinya akan disampaikan. Pada tahap menganalisis dan evaluasi peserta didik akan divaluasi agar dapat diketahui seberapa pemahaman peserta didik terhadap materi yang didapatkan selama kegiatan pembelajaran. Dengan model pembelajaran problem based learning diharapkan pembelajaran yang terjadi dapat lebih bermakna dan memberi kesan yang kuat kepada peserta didik sehingga dapat meningkatkan pemahaman konsep matematika peserta didik. Disamping itu, untuk memperkuat konsep tersebut peserta didik juga diarahkan untuk selalu merangkum materi yang telah mereka dapatkan serta latihan soal-soal. Perangkuman materi dan latihan soal merupakan bentuk feed back yang diberikan guru melalui portofolio. Fortopolio merupakan kumpulan ringkasan materi dan latihan soal siswa yang dikumpulkan dan dievaluasi oleh guru. Hal tersebut memungkinkan guru mengetahui perkembangan peserta didik secara intensif. Berdasarkan uraian di atas, maka penelitian mengambil judul penelitian "Penerapan Model Pembelajaran Problem Based Learning Berbantuan Portofolio untuk Meningkatkan Pemahaman Konsep Matematika Peserta Didik Kelas XI APH C SMK Negeri 1 Singaraja Tahun Pelajaran 2018/2019".

Berdasarkan latar belakang di atas, maka rumusan masalah pada penelitian ini adalah "Bagaimana peningkatan pemahaman konsep peserta didik kelas XI APH C SMK Negeri 1 Singaraja tahun pelajaran 2018/2019 melalui penerapan model pembelajaran problem based learning berbantuan portofolio?". Adapun tujuan dari penelitian ini adalah untuk meningkatkan pemahaman konsep matematika peserta didik kelas XI APH C SMK Negeri 1 Singaraja tahun pelajaran 2018/2019 melalui penerapan model problem based learning berbantuan portofolio.

\section{Metode Penelitian}

Rancangan penelitian yang digunakan dalam penelitian ini adalah penelitian tindakan kelas (Classroom Action Research). Penelitian tindakan kelas merupakan upaya perbaikan yang dilakukan dengan cara melakukan tindakan untuk mencari jawaban atas permasalahan yang diangkat atau ditemukan di kelas. 
Penelitian ini dilaksanakan dalam dua siklus, dengan maksud untuk mengetahui perkembangan perubahannya dan dapat melakukan tahapan perbaikan dengan baik. Secara garis besar pelaksanaan penelitian ini dapat digambarkan sebagai berikut:

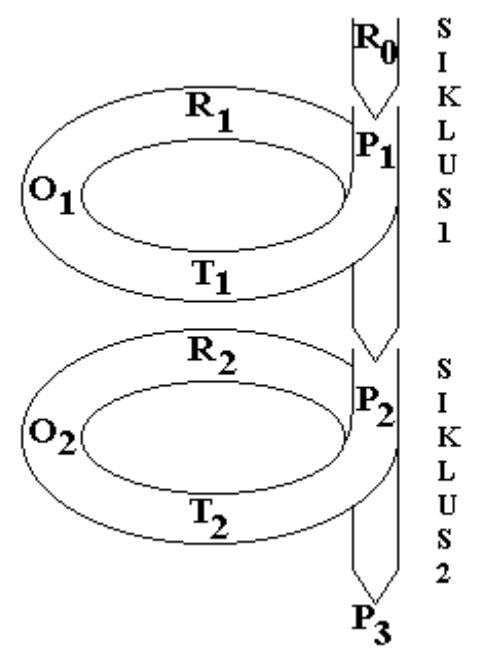

$$
\begin{aligned}
& \text { Keterangan : } \\
& \mathrm{R}_{0}=\text { Refleksi awal (perenungan) } \\
& \mathrm{P}_{1}=\text { Perencanaan } 1 \\
& \mathrm{~T}_{1}=\text { Tindakan } 1 \\
& \mathrm{O}_{1}=\text { Observasi } 1 \\
& \mathrm{R}_{1}=\text { Refleksi } 1 \\
& \mathrm{P}_{2}=\text { Perencanaan } 2 \\
& \mathrm{~T}_{2}=\text { Tindakan } 2 \\
& \mathrm{O}_{2}=\text { Observasi } 2 \\
& \mathrm{R}_{2}=\text { Refleksi } 2
\end{aligned}
$$

Gambr 1 Alur PTK Model Spiral Adaptasi dari Kemmis dan Taggart

Subjek dalam penelitian ini adalah peserta didik kelas XI APH C SMK Negeri 1 Singaraja semester ganjil tahun ajaran 2018/2019, hal tersebut dikarenakan di kelas tersebut peneliti mendapatkan permasalahan mengenai pemahaman konsep siswa yang kurang, sehingga berdampak pada hasil belajarnya yang rendah. Sedangkan objek dalam penelitian tindakan kelas yang dilakukan ini adalah kemmpuan pemahaman konsep matematika peserta didik kelas XI APH C SMK Negeri 1 Singaraja melalui penerapan model pembelajaran Problem Based Learning (PBL) berbantuan Portofolio.

Penelitian ini merupakan penelitian tindakan kelas yang dilaksanakan dalam dua siklus. Selain tahap pra tindakan setiap siklus meliputi 4 (empat) tahap kegiatan, yaitu tahap perencanaan, tahap pelaksanaan tindakan, tahap pengamatan dan tahap refleksi. Teknik pengumpulan data pada penelitian ini berupa tes. Teknik pengumpulan data untuk pemahaman konsep matematika peserta didik melalui model Problem Based Learning berbantuan portofolio. Analisis data pemahaman konsep matematika siswa dilakukan dengan menghitung rata-rata nilai pemahaman konsep matematika siswa $(M)$ dengan rumus :

$$
M=\frac{\sum_{i=1}^{n} x_{i}}{n}
$$

Keterangan:

(Koyan. 2007:75)

$M$ : rata-rata nilai tes pemahaman konsep matematika siswa

$x_{i}$ : nilai tes pemahaman konsep matematika siswa ke $-i$

$n$ : banyak siswa

Selanjutnya data pemahaman konsep matematika siswa tersebut dikualifikasikan berdasarkan kriteria penggolongan pemahaman konsep matematika siswa seperti pada Tabel 2 berikut.

Tabel 2. Kriteria Penggolongan Pemahaman Konsep Matematika Siswa

\begin{tabular}{|l|l|l|}
\hline No & \multicolumn{1}{|c|}{ Kriteria } & \multicolumn{1}{c|}{ Kategori } \\
\hline 1 & $M \geq M_{i}+1,8 S d_{i} \quad$ Sangat Tinggi \\
\hline 2 & $M_{i}+1,8 S d_{i}>M \geq M_{i}+0,6 S d_{i}$ & Tinggi \\
\hline
\end{tabular}




\begin{tabular}{|l|l|l|}
\hline 3 & $M_{i}+0,6 S d_{i}>M \geq M_{i}-0,6 S d_{i}$ & Cukup Tinggi \\
\hline 4 & $M_{i}-0,6 S d_{i}>M \geq M_{i}-1,8 S d_{i}$ & Kurang \\
\hline 5 & $M<M_{i}-1,8 S d_{i}$ & Sangat Kurang \\
\hline
\end{tabular}

(Dimodifikasi dari Candiasa,2010)

$$
\begin{aligned}
\mathrm{M}_{\mathrm{i}} & \left.=\frac{1}{2} \text { (nilai tertinggi ideal }+ \text { nilai terendah ideal }\right) \\
\mathrm{Sd}_{\mathrm{i}} & =\frac{1}{3} \times \mathrm{M}_{\mathrm{i}}
\end{aligned}
$$

Tes pemahaman konsep matematika siswa yang digunakan dalam penelitian ini berupa tes uraian. Dalam hal ini, nilai tertinggi ideal adalah 100 dan nilai terendah ideal adalah 0 , sehingga mean ideal $\left(\mathrm{M}_{\mathrm{i}}\right)$ dan standar deviasi $\left(\mathrm{SD}_{\mathrm{i}}\right)$ adalah sebagai beikut.

$$
\begin{array}{rlr}
\mathrm{M}_{\mathrm{i}} & =\frac{1}{2}(\text { nilai tertinggi ideal }+ \text { nilai terendah ideal }) \\
= & \frac{1}{2}(100+0) & =50 \\
\mathrm{Sd}_{\mathrm{i}}= & \frac{1}{3} \times M_{i} & =16,67
\end{array}
$$

Dengan demikian, data pemahaman konsep matematika siswa ditentukan dengan kriteria yang dinyatakan dalam Tabel 3 berikut.

Tabel 3. Kriteria Penggolongan Pemahaman Konsep Matematika Siswa yang Telah Dimodifikasi dengan Nilai Tes Pemahaman Konsep Matematika

\begin{tabular}{|l|l|l|}
\hline No & \multicolumn{1}{|c|}{ Rentang Nilai } & \multicolumn{1}{c|}{ Sangat Baik } \\
\hline 1 & $M \geq 80,006$ & Sangat Baik \\
\hline 2 & $60,002 \leq M<80,006$ & Baik \\
\hline 3 & $39,998 \leq M<60,002$ & Cukup Baik \\
\hline 4 & $19,994 \leq M<39,998$ & Kurang \\
\hline 5 & $M<19,994$ & Sangat Kurang \\
\hline
\end{tabular}

(Dimodifikasi dari Candiasa, 2010)

Kriteria Paling rendah untuk menyatakan peserta didik mencapai ketuntasan dinamakan Kriteria Ketuntasan Minimal (KKM). Rata-rata nilai pemahaman konsep matematika siswa minimal berada pada kategori baik dan memenuhi kriteria minimal 73 pada setiap siklusnya. Kriteria minimal tersebut mempertimbangkan karena SMK Negeri 1 Singaraja telah menentukan kriteria ketuntasan minimal (KKM) yaitu 73. Hasil belajar peserta didik secara klasikal minimal $75 \%$ peserta didik telah memperoleh skor $\geq 75$ ( KKM di sekolah).

\section{Hasil dan Pembahasan}

Dari hasil analisis data pemahaman konsep matematika siswa pada siklus I terlihat bahwa nilai tertinggi adalah 95 dan nilai terendah adalah 35 dari nilai maksimum 100 dan nilai 
minimum 0. Presentase pemahaman konsep matematika siswa pada siklus I untuk masingmasing kategori disajikan pada Tabel 4 berikut.

Tabel 4. Presentase Pemahaman Konsep Matematika Siswa Siklus I

\begin{tabular}{|l|l|l|l|l|l|}
\hline & $\begin{array}{l}\text { Sangat } \\
\text { Kurang }\end{array}$ & Kurang & Cukup Baik & Baik & Sangat Baik \\
\hline $\begin{array}{l}\text { Banyak } \\
\text { Siswa }\end{array}$ & 0 & 1 & 15 & 16 & 2 \\
\hline Presentase & $0 \%$ & $2,86 \%$ & $42,86 \%$ & $48,57 \%$ & $5,71 \%$ \\
\hline
\end{tabular}

Berdasarkan data pemahaman konsep matematika siswa diketahui hal-hal berikut. Jumlah nilai pemahaman konsep matematika siswa

$$
\left(\sum_{i=1}^{34} x_{i}\right)=2350
$$

Banyak siswa $(n)=34$ orang

Rata-rata nilai pemahaman konsep matematika siswa yaitu

$$
M=\frac{\sum_{i=1}^{34} x_{i}}{n}=\frac{2350}{34}=69,12
$$

Jika dikategorikan berdasarkan kriteria penggolongan pemahaman konsep matematika siswa yang telah ditetapkan, maka pemahaman konsep matematika siswa termasuk dalam kategori baik. Namun rata-rata nilai pemahaman konsep matematika siswa belum memenuhi kriteria minimal yaitu 73 .

Dari analisis tersebut, dapat disimpulkan bahwa pelaksanaan tindakan pada siklus I belum memenuhi kriteria indikator keberhasilan yang telah ditetapkan, karena rata-rata nilai pemahaman konsep matematika siswa pada siklus I yaitu 69,12 belum memenuhi kriteria minimal 73.

Data pemahaman konsep matematika siswa pada siklus III disajikan dalam Lampiran 29. Berdasarkan hasil analisis data pemahaman konsep matematika siswa pada siklus III terlihat bahwa nilai tertinggi adalah 96,15 dan nilai terendah adalah 46,15 dari nilai maksimum 100 dan nilai minimum 0 . Presentase pemahaman konsep matematika siswa pada siklus III untuk masing-masing kategori disajikan pada Table 5 berikut.

Tabel 5. Presentase Pemahaman Konsep Matematika Siswa Siklus II

\begin{tabular}{|l|l|l|l|l|l|}
\hline & $\begin{array}{l}\text { Sangat } \\
\text { Kurang }\end{array}$ & Kurang & Cukup Baik & Baik & Sangat Baik \\
\hline $\begin{array}{l}\text { Banyak } \\
\text { Siswa }\end{array}$ & 0 & 0 & 5 & 19 & 10 \\
\hline Presentase & $0 \%$ & $0 \%$ & $14,29 \%$ & $54,29 \%$ & $31,42 \%$ \\
\hline
\end{tabular}

Berdasarkan data pemahaman konsep matematika siswa diketahui hal-hal berikut. Jumlah nilai pemahaman konsep matematika siswa yaitu sebagai berikut.

$$
\left(\sum_{i=1}^{34} x_{1}\right)=2560
$$

Banyak siswa $(n)=34$ orang. Rata-rata nilai pemahaman konsep matematika siswa yaitu sebagai berikut. 


$$
M=\frac{\sum_{i}^{34} x_{1}}{n}=\frac{2560}{34}=75,29
$$

Jika dikategorikan berdasarkan kriteria penggolongan pemahaman konsep matematika siswa yang telah ditetapkan, maka pemahaman konsep matematika siswa termasuk dalam kategori baik.

Berdasarkan analisis data di atas, dapat disimpulkan bahwa rata-rata nilai pemahaman konsep matematika siswa kelas XI APH C SMK Negeri 4 Singaraja sudah memenuhi indikator keberhasil karena rata-rata nilai pemahaman konsep matematika siswa pada siklus II yaitu 75,29 sudah berada pada kategori baik dan memenuhi kriteria minimal 73. Di samping itu, rata-rata nilai pemahaman konsep matematika siswa mengalami peningkatan dari siklus II ke siklus II sebesar 6,17\% yaitu dari 69,12 menjadi 75,29. Berdasarkan hal tersebut, dapat disimpulkan bahwa peningkatan pemahaman konsep matematika siswa secara optimal terjadi pada siklus II.

\section{Simpulan}

Berdasarkan hasil penelitian dan pembahasan dalam penelitian ini dapat disimpulkan sebaga berikut. Penerapan model pembelajaran Problem Based Learning yang berbantuan Portofolo dapat meningkatkan pemahaman konsep matematika peserta didik di kelas XI APH C SMK Negeri 1 Singaraja pada materi pokok Persamaan dan Fungsi Kuadrat. Hal ini dapat dilihat dari rata-rata persentase kemampuan pemahaman konsep matematika belajar peserta didik secara klasikal mencapai $69,12 \%$ pada siklus I dan mencapai $75,29 \%$ pada siklus II, dengan demikian peserta didik dapat dikategorikan telah memiliki kemampuan pemahaman konsep matematika yang baik.

\section{Daftar Pustaka}

Arikunto, S.dkk. 2009. Penelitian Tindakan Kelas. Jakarta: PT Bumi Aksara.

Azwar, S. 2010. Penyusunan Skala Psikologi. Yogyakarta: Pustaka Pelajar.

Djamarah, Syaiful Bahri. 2012. Prestasi Belajar dan Kompetensi Guru. Surabaya: Usaha Nasional.

Candiasa, 2010. Analisis Statistika. Singaraja. Undiksha.

Iru dan Arihi. 2012. Analisis Penerapan Pendekatan, Metode, Strategi, dan Model-model Pembelajaran. DIY: Multi Presindo.

Mahmud, 2011. Metode Penelitian Pendidikan. Bandung: Pustaka Setia

Nurkanca. (1990). Evaluasi Pendidikan. Surabaya: Usaha Nasional.

Peraturan Pemeritahan RI Nomor32 Tahun 2013 tentangPerubahan atas peraturan pemerintah No 19 Tahun 2005 tentang standar Nasional Pendidikan. Tersedia di http://sindikker.ristekdikti.go.id/dok/PP/PP32-2013PerubahanPP19-2005SNP.pdf

Rusman. 2010. Model-model Pembelajaran Mengembangkan Profesionalisme Guru. Bandung: Rajawali press. Setiadi, H. 2006. Penilaian Kinerja. Jakarta: Depdiknas.

Rusman. 2012. Belajar dan Pembelajaran Berbasis Komputer Mengembangkan Profesionalisme Guru Abad 21. Bandung: ALFABETA. 
Rusman. 2013. Model-model Pembelajaran Mengembangkan Profesionalisme Guru. Jakarta: Raja Grafindo Persada 